\title{
THE ACQUISITION OF ENGLISH VOCABULARY BY KINDERGARTEN STUDENTS THROUGH CHILDREN SONGS
}

\author{
Ida Ayu Made Yuni Andaria , Ida Bagus Alit Arta Wigunab \\ aUniversitas Udayana, 'Institut Agama Hindu Negeri Gde Pudja Mataram \\ a idaayuyunii@gmail.com, b gusarta@iahn-gdepudja.ac.id
}

(Diterima: 07 Januari 2022; Direvisi: 17 Januari 2022; Diterbitkan: 31 Januari 2022)

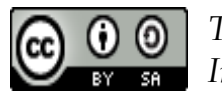

This work is licensed under a Creative Commons Attribution-ShareAlike 4.0

International License

\begin{tabular}{l}
\hline Keywords: \\
\hline Language \\
Acquisition, \\
Vocabulary, Young \\
Learner, Children \\
Songs
\end{tabular}

Kata kunci:

Akuisisi Bahasa, Kosakata, Anak Usia dini, Lagu Anak-anak

\begin{abstract}
This study focuses on how the process of students in acquiring language. This study aims to find out kinds of vocabulary that the young learners acquire through children song and analyze how the internal and external factors influence the process of language acquisition. The data in this study were 10 students from Hooray School In collecting the data, observation method and questioners were used. Observation was conducted for three weeks and post-test is given to the students in the last meeting of each week. Questioners is given to the students' parents to know information about factors influence the students in learning English. The result of this study showed that English children songs are effective media to be used in acquiring language for children. In this study, there are 2 songs introduced to the students. From the lyrics of those songs, they are able to acquire English vocabularies, such as shark, octopus, jellyfish, turtle, dolphin, seahore, swim, and sea. In acquiring languages, the students are influenced by some factors. The internal factors are age, experience and learning style. The external factors consist of motivation, instruction and access to foreign speakers. The students who are surrounded by an English speaking environment learn English vocabularies faster and easier than the other students who are not surrounded by an English speaking environment.
\end{abstract}

\begin{tabular}{l} 
Abstrak \\
\hline Penelitian ini berfokus pada bagaimana proses siswa dalam \\
memperoleh bahasa. Penelitian ini bertujuan untuk \\
mengetahui jenis kosa kata yang diperoleh anak usia dini \\
melalui lagu anak-anak dan menganalisis bagaimana faktor \\
internal dan eksternal mempengaruhi proses pemerolehan \\
bahasa. Data dalam penelitian ini adalah 10 siswa di Horray \\
\hline
\end{tabular}


School. Dalam teknik pengumpulan data digunakan metode
observasi dan angket. Observasi dilakukan selama tiga
minggu dan post-test diberikan kepada siswa pada
pertemuan terakhir setiap minggunya. Kuesioner diberikan
kepada orang tua siswa untuk mengetahui informasi tentang
faktor-faktor yang mempengaruhi siswa dalam belajar
bahasa Inggris. Hasil penelitian ini menunjukkan bahwa
lagu anak berbahasa Inggris merupakan media yang efektif
untuk digunakan dalam pemerolehan bahasa bagi anak.
Dalam penelitian ini, ada 2 lagu yang diperkenalkan kepada
siswa. Dari lirik lagu-lagu tersebut, siswa mampu
menguasai kosakata bahasa Inggris, seperti shark, octopus,
jellyfish, turtle, dolphin, seahore, swim, dan sea. Dalam
memperoleh bahasa, siswa dipengaruhi oleh beberapa faktor.
Faktor internal adalah usia, pengalaman dan gaya belajar.
Faktor eksternal terdiri dari motivasi, instruksi dan akses ke
penutur asing. Siswa yang dikelilingi oleh lingkungan
berbahasa Inggris belajarkosakata bahasa Inggris lebih cepat
dan lebih mudah daripada siswa lain yang tidak dikelilingi
oleh lingkungan berbahasa Inggris.

\section{INTRODUCTION}

Language is an intricate and dynamic arrangement of regular images utilized in different contemplations and correspondence (Connell, 1987). Language assumes a significant part in our everyday existence. It is a result of the language used to communicate our brains or thoughts. It very well may be through composition, singing, motions, set principles that permit individuals discourse, or other correspondence implies (Brown, 2000). It includes trading musings, thoughts, or feelings.

Little youngsters can get language. They might secure language through cooperation with their folks and different grown-ups, or it very well may be with different youngsters (Wiguna \& Ekaningtyas, 2021). They typically procure language that is being utilized around them. Kids can even communicate in two dialects simultaneously as long as they are routinely associating with speakers of those dialects (Fillmore, \& Snow, 2018).

As per (Chomsky, 1965) language is a natural workforce. It is believed that youngsters were brought into the world with a bunch of rules concerning language to them. It is on the grounds that kids were brought into the world with a natural comprehension of the manner in which language work, they can gain language absent a lot of exertion.

As indicated by (Hasa, 2020), kids can get more than one language. As a rule, language securing can be separated into two, which are first and second language obtaining. First language securing is youngsters' obtaining of their local language. In the interim, second language procurement is learning a language after they gain 
their first language or first language. The first is connected with the inner mind process, however the second has a place with a functioning and cognizant interaction (Wiguna, 2021).

(ASHA, 2020) states that youngsters procure and gain language began from when they were children. Aside from Bahasa Indonesia as their primary language, they additionally secure English. Associations with individuals' environmental factors, watching recordings, tuning in, and singing youngsters' melodies are a few exercises that goodly affect kids' language securing, particularly in English. They can assimilate jargon as the primary resource for fathom English.

One of the nearest and most fascinating things to kids is melodies. They can pay attention to the tune, watch the video, or sing the melody. Kids who routinely pay attention to the melody might begin murmuring, and afterward unwittingly, they might retain a portion of the vocabularies, and on the off chance that they continue to tune in, at long last they can sing the tune. It demonstrates the language obtaining process. Youngsters gain vocabularies through kids' tunes (Suhcera, 2018).

In light of (Novak, 2014), the language utilized in youngsters' melodies is normally basic. It is additionally connected with a specific subject, for example: portions of the body, names of organic products, sorts of vegetables, things in the sky, every day exercises, and others. Those are the topics that are near the youngsters' life. Moreover, youngsters' tunes as a rule have a great time beat with the goal that kids are cheerful when they tune in or sing the tune.

Practically the entirety of youngsters' melodies have simple vocabularies to comprehend. Normally, the writers utilize the subjects that youngsters love, as toys or frozen yogurt. Plus, they likewise utilize an entertaining word that sounds extraordinary. A large portion of the kids' melodies likewise welcome them to do specific exercises. For this situation, kids might get the opportunity to tune in and follow headings. They need to focus and know about what is happening to follow and take an interest well.

One of the extraordinary qualities of kids' melodies is the utilization of reiteration. It makes the tune is more straightforward on the grounds that the youthful personalities don't ingest a lot of data all at once. Notwithstanding, the redundancy builds up messages and makes the tunes are not difficult to recall.

In a word, youngsters' tunes enjoy a few benefits for kids to obtain language, particularly English. This review centers around noticing kids' language procurement by youngsters' melodies. A few Hooray School's kids at age 4-5 years of age were noticed (Wiguna, 2020). At that age, aside from singing, they additionally begin to get the hang of perusing and composing. Likewise, Hooray School is perhaps the best school in Bali, which is 
utilizing bilinguals during the communication. These are at last prompted a plan to examine the sort of jargon procured by the youthful students through kids' melodies. It is likewise vital to the inside and outside factors that impact the securing of jargon obtained by the youngsters. Subsequently, this review is entitled The Acquisition of Vocabulary by the Young Learners through Children Songs (Kurniati \& Widyastuti, 2019).

The issue in this examination is Young students procure what sorts of jargon through kids' melodies. To discover what sorts of jargon that the youthful students secure through youngsters' melodies. A particular and restricted theme is needed in an examination paper. The conversation of this review zeroed in on the jargon securing of understudies in Hooray School through youngsters' tunes. Talked about in this examination are the sorts of jargon obtained by youthful students through youngsters' melodies.

\section{METHOD}

The qualitative technique was utilized to investigate the information are additionally broke down as per Chomsky's hypothesis as the fundamental hypothesis and upheld different speculations of language obtaining (Chomsky, 1972). The investigation was connected to the issues that are figured. In this examination, the information were dissected in more ways than one. It was distinguishing the vocabularies that the kids were effectively replying.

The information wellspring of this review was taken from Hooray School's understudies in Denpasar. The understudies were picked for this review were in kindergarten A which comprised of two classes, Green leaf, and Jelly Jungle. The times of the understudies were 4-5 years of age. There were 20 understudies. All of the kindergarten An understudies were utilized as tests for this exploration. The strategy for gathering information is the documentation technique through field exploration and library research.

The information was gathered by doing perception (Sugiyono, 2009), giving polls to the guardians, and doing an immediate meeting with the understudies. In the first place, the understudy's movement in the class for a month was noticed. Every one of the understudies' exercises were noticed. The perception was finished by taking a gander at every understudy and taking notes. It was begun with the understudy 'coming, welcoming, singing, learning, and leaving. It was done to get the data from the learning system that had been finished. The main issue was investigated by the information source, which was acquired from direct meetings to the understudies helped with a vocabularies agenda.

\section{RESULT AND DISCUSSION}

This part centers around the kind of English vocabularies acquired 
by the youthful students through English kids melodies in three weeks. These melodies are oftentimes tuned in by the kindergarten understudies in each class exercises. The Students at five years old can finish orders without requiring a provoking.

Songs can be a help in acquiring English vocabularies (Wiasti, 2021). It is because songs are simple and fun, therefore they are easy to teach and learn. The song serves as multipurpose input material of delivering oral language instruction to children. It is audiovisual and highly motivational. In addition, the songs make young learners not only act as people who speak the language, but also the way they respond to what others say. The children songs are chosen because they are an interesting and attractive environment that makes the children enjoy learning the language.

From the explanation above, the learning situations with songs are very fun and interesting for young learners. In this case, the observation are made every week and will be given different songs every week, totally three songs for three weeks given to the young learners. In English learning process, one different song is introduced every week. Effective days for children to study at school are five days, Monday to Friday. In each day, the students were given different learning activities with song.

On the first week of Monday to Thursday the meeting was held by introducing the song entitled "Head,
Shoulders, Knees \& Toes" and especially on Friday there would be a simple post-test with pictures related to the vocabulary obtained in the song entitled on the second week from Monday to Thursday, the meeting was held by introducing the song entitled "If You're Happy" and especially on Friday there would be a simple posttest with pictures related to the words found in the song. entitled "If You're Happy." Then, on the third week from Monday to Thursday, the meeting was held by introducing a song entitled "A Sailor Went to Sea" and on Friday, a simple post-test with pictures related to vocabulary was given. Furthermore, the results of the post-test are described in table form and words. This post test shows the results of type of vocabularies obtained by students in acquiring English through children songs. The analysis of types of English vocabularies acquired by young learners through English songs can be seen as follow:

\subsection{The song entitled "If you're happy"}

The song entitled "If you're happy" is great for helping the young learners in body movement. Body movement is an important step in children's development. The "If you're happy" song loved by many kids, since it allows kids to get active while having fun and as to avoid the child from feeling bored by doing a little play when listen this song.

The actions or movements were introduced to the children when they 
heard the word clap, stomp, 'oh no!' and take a nap. Then, students were asked to move and sing according to the song and children must copy the movements that were introduced with special instructions for a certain word that pop up in the song. The students were excited and happily singing and dancing when the song played. After the words they had learnt being recalled and most of them had memorized it correctly. The young learners will know how to expressed the body movement into words.
On the second week of the observation, there is a new song introduced. The learning process through the song entitled "If you're Happy" is explained as follows:

The first meeting was on March 08th, 2021. The learning process on the first day in second week was performed some activities: greetings by the teacher and students before the learning activities. Then, introduction the students to the song "If you're happy." The lyrics of this song are presented below:

\section{"If you're Happy Lyrics"}

If you're happy happy happy, clap your hands.

If you're happy happy happy, clap your hands.

If you're happy happy happy, clap your hands, clap your hands.

If you're happy happy happy, clap your hands.

If you're angry angry angry, stomp your feet.

If you're angry angry angry, stomp your feet.

If you're angry angry angry, stomp your feet, stomp your feet.

If you're angry angry angry, stomp your feet.

If you're scared scared scared, say, "Oh no!"

If you're scared scared scared, say, "Oh no!"

If you're scared scared scared, say, "Oh no!" Say, "Oh no!"

If you're scared scared scared, say, "Oh no!"

If you're sleepy sleepy sleepy, take a nap.

If you're sleepy sleepy sleepy, take a nap.

If you're sleepy sleepy sleepy, take a nap, take a nap.

If you're sleepy sleepy sleepy, take a nap.

If you're happy happy happy, clap your hands.

If you're happy happy happy, clap your hands.

If you're happy happy happy, clap your hands, clap your hands.

If you're happy happy happy, clap your hands.

The teacher show actions or movements were introduced to the children when they heard the word clap, stomp, 'oh no!' and take a nap.
Then, students were asked to move and sing according to the song. The students must copy the movements that were introduced with special 
instructions for a certain word that pop up in the song. The song were repeatedly sung in this meeting. All the students were excited and hapily singing and dancing when the song played.

The second meeting was on March 09th, 2021. The learning process on the second day in second week was performed not much different from the first day. In the beginning, before starting learning activities, the teacher was greeting the students. Furthermore, the teacher asked the students to move their body along with the song. Some of the students who was very active in the class, they are Dastan, Miko, Tama, Clairy, Almirah, and Moniq. In this meeting, they moved correctly according to the song. The other students named Abhi, Karina, RInggo and Aftan made some mistakes in the movement. The song is sung again by the student as the last activity of this meeting. The last activity is to recap the words they had to learn in this song.

The third meeting was on March 10th, 2021. The learning process on the third day was performed not much different from the first day. In the beginning, before starting learning activities, the teacher greeting the students. After that, they recalled the song "If you're Happy." The song were repeatedly sung in this meeting. The students were asked questions by showing pictures according to the vocabulary in this song. The students named Miko, Moniq, Dastan, Tama, Clairy, and Almirah are able to answer the emotions questions correctly. The other students named Abhi, Karina, Ringgo, and Aftan could not to answer the emotions questions correctly. They made some mistakes in the questions.

The fourth meeting was on March 11th, 2021. In the morning, the teacher asked the student about what are they feeling, like happy, scared, sleepy and sad. Then the teacher asked if they could move along with the lyrics of the song. The students can follow it enthusiastically. After that, each student come in front of the class to describe with the face and do the body movement based on the vocabulary in the song. The students named Miko, Moniq, Dastan, Tama, Clairy, and Almirah described the movement well. The other students named Abhi, Karina, Ringgo, and Aftan made a mistake in sleepy, stomp, and take a nap movement. In this meeting, the song was also sung repeatedly.

From the learning process observation, it can be seen that Miko, Moniq, Dastan, Abhi, Tama, Clairy, and Almirah are the most active students. It is because they like moving activities with the song and they are very enthusiast. The other students named Karina, Ringgo, and Aftan do not stand out at every meeting. It is because they do not understand the words when learning activities. As the result, they made some mistakes. Generally, the students' performance in required the name of fave emotions in English was almost perfect, 
although, there were some students who could not do it.

Then on the last day of the second week, the simple pictures of post-test will be given by choosing multiple choices. The fifth meeting was on March 12th, 2021. In this meeting, the students were given the post-test with the vocabulary contained in the song "If you're happy." The post-test is given in the form of a multiple-choice test and shows a picture containing seven questions based on the vocabulary in this song. The vocabulary taught in this meeting is explained as follows:

Happy, angry, scared, sleepy, clap, stomp, and take a nap.

The result of post-test of the students is presented by using a table, vocabulary children songs entitled "If you're happy" as follows:

Table 3.2 The result of the students post test from "If you're happy" song

\begin{tabular}{ccccccccc}
\hline No & $\begin{array}{c}\text { Student } \\
\text { names }\end{array}$ & \multicolumn{7}{c}{ Kinds of Vocabulary } \\
& & Happy & Angry & Scared & Sleepy & Clap & Stomp & Take a nap \\
\hline 1. & Miko & $\sqrt{ }$ & $\sqrt{ }$ & $\sqrt{ }$ & $\sqrt{ }$ & $\sqrt{ }$ & $\sqrt{ }$ & $\sqrt{ }$ \\
2. & Moniq & $\sqrt{ }$ & $\sqrt{ }$ & $\sqrt{ }$ & $\sqrt{ }$ & $\sqrt{ }$ & $\sqrt{ }$ & $\sqrt{ }$ \\
3. & Dastan & $\sqrt{ }$ & $\sqrt{ }$ & $\sqrt{ }$ & $\sqrt{ }$ & $\sqrt{ }$ & $\sqrt{ }$ & $\sqrt{ }$ \\
4. & Abhi & $\sqrt{ }$ & $\sqrt{ }$ & $\sqrt{ }$ & $\sqrt{ }$ & $\sqrt{ }$ & $\sqrt{ }$ & X \\
5. & Karina & $\sqrt{ }$ & $\sqrt{ }$ & $\sqrt{ }$ & X & $\sqrt{ }$ & $\sqrt{ }$ & X \\
6. & Ringgo & $\sqrt{ }$ & $\sqrt{ }$ & $\sqrt{ }$ & X & $\sqrt{ }$ & X & $\sqrt{ }$ \\
7. & Tama & $\sqrt{ }$ & $\sqrt{ }$ & $\sqrt{ }$ & $\sqrt{ }$ & $\sqrt{ }$ & $\sqrt{ }$ & $\sqrt{ }$ \\
8. & Clairy & $\sqrt{ }$ & $\sqrt{ }$ & $\sqrt{ }$ & $\sqrt{ }$ & $\sqrt{ }$ & $\sqrt{ }$ & $\sqrt{ }$ \\
9. & Aftan & $\sqrt{ }$ & $\sqrt{ }$ & $\sqrt{ }$ & $X$ & $\sqrt{ }$ & $\sqrt{ }$ & X \\
10. & Almirah & $\sqrt{ }$ & $\sqrt{ }$ & $\sqrt{ }$ & $\sqrt{ }$ & $\sqrt{ }$ & $\sqrt{ }$ & $\sqrt{ }$ \\
\hline
\end{tabular}

The symbol above $(\sqrt{ })$ indicates the students can acquire the vocabularies of body parts. Meanwhile (X) indicates that the students cannot acquire the vocabulary. The following subsections are explanation about the result of the post-test, started from If you're happy songs.

The post-test results showed that the students had good vocabulary mastery. This can be seen from the table above. There are six out of ten students who answered all the vocabularies correctly. They are Miko,
Moniq, Dastan, Tama, Clairy, and Almirah. Four other students made small mistakes in answering the posttest questions related to emotions movement. It is because they forgot the vocabulary. Abhi made mistake in take a nap. Ringgo made mistake in sleepy, stomp. Aftan and Karina made mistake in sleepy and take a nap.

There are seven vocabularies found in the song entitled "If you're happy," such as: happy, angry, scared, clap, sleepy, stomp, take a nap, and stomp. From the explanation above, 
this song can help the student to learn or acquired English vocabs related to emotions, adjective and activites.

\subsection{Children Song entitled "A Sailor Went to Sea"}

"A Sailor Went to Sea" is one of the nursery rhymes and popular children song. This song is great for helping the young learner to know about the sailor's adventures while singing. In this song, the children are going to learn about the types of sea animals. Moreover, they also introduce to the habitat of the animals.

This song is quite short that makes the children will acquired in one pass. Furthermore, they will be happy to sing along because it makes them imagine being pirates and sailors on adventures (Curtis, 2004). This song will help the young learners to introduce how people used to be in the village. There were so many seafaring people in the village. All the kids had to watch their parents went out to sea. Since they often did this activity, they turn it into a song. It is because it helped them to make sure that they could associate something happy with their fathers went to sea for weeks at a time. Furthermore, they were happier to send their fathers while singing this song.

On the third week of the observation, this song introduced. The learning process through children song entitled "A Sailor Went to Sea" is explained as follows:

The first meeting was on March 15th, 2021. They performed some activities: greetings by the teacher and students before the learning process. Then, the students is introduced to the song "A Sailor Went to Sea." The lyrics of this song are presented below:

\section{"A Sailor Went to Sea Lyrics"}

A sailor went to sea, sea, sea

To see what she could see, see, see

But all that she could see, see, see

Was the bottom of the deep blue sea, sea, sea

A sailor went to sea, sea, sea

To see what she could see, see, see

But all that she could see, see, see

Was a baby shark in the deep blue sea

A sailor went to sea, sea, sea

To see what she could see, see, see

But all that she could see, see, see

Was an octopus in the deep blue sea

A sailor went to sea, sea, sea

To see what she could see, see, see

But all that she could see, see, see

Was a jellyfish swimming 
A sailor went to sea, sea, sea

To see what she could see, see, see

But all that she could see, see, see

Was a turtle in the deep blue sea

A sailor went to sea, sea, sea

To see what she could see, see, see

But all that she could see, see, see

Was a dolphin in the deep blue sea

A sailor went to sea, sea, sea

To see what she could see, see, see

But all that she could see, see, see

Was a seahorse swimming

A sailor went to sea, sea, sea

To see what she could see, see, see

But all that she could see, see, see

Was the bottom of the deep blue sea, sea, sea

The movements were introduced to the children when they heard the word of see, sea, seahorse, jellyfish, turtle, octopus, baby shark and blue whale. The word see and sea have the same pronunciation but different meaning. In order to make them different, the teacher gave a gesture of pointing at eyes when the word 'see' is sung. Meanwhile, for the word 'sea', the teacher ask the students to imagine looking at sea while spreading their arms and making a gesture of looking at the sea. Then, the children move and sing along according to the song and children must copy the movements that were introduced with the special instructions for a certain word that pop up in the song. The song was repeatedly sung in this meeting. All of the students were dancing according to the song happily.

The second meeting was on March 16th, 2021. The learning process on the second day was performed not much different from day one. In the beginning, before starting the learning activities, the teacher was greeting the students first by saying, "hello, good morning, and how are you?". Furthermore, one by one the students were asked to appear in front of the class. The teacher will guide to move, and each person must imitate the movements of sea animals from their friends in front of the class correctly. The song was repeatedly sung in this meeting. The students were happily singing and dancing according to the song. The students named Miko, Dastan, Abhi, Tama, Clairy, and Almirah described the movement very well. The other students named Moniq, Karina, Ringgo, and Aftan made a mistake in octopus, jellyfish and sea. As the result, they cannot follow the movements of sea animals because 
they do not remember some of those words.

The third meeting was on March 17th, 2021. The students must memorize the sea animals arrangement from the song and all the students sang along together. The song was repeatedly sung in this meeting. When the song has ended, some students were pointed according to the seating line and mentioned the sea animals' arrangement according to their line. Then, the student that got the point first must have mentioned the name of the sea animals that first popped in the song and keep going until the last line. The words they had learned were recalled, and they managed to memorize the words correctly and mentioned the sea animals arrangement in the song correctly. The students named Miko, Dastan, Abhi, Tama, Clairy, and Almirah were able to acquire some English vocabularies, such as are shark, octopus, jellyfish, turtle, dolphin, seahorse, swim, sea. The other students named Moniq, Karina, Ringgo, and Aftan could not to remember some words related to sea animals, such as are octopus, jellyfish and sea.

The fourth meeting was on March 18 th, 2021. In the morning, the teacher asked the student about what do they feel? Furthermore, the teacher gave recalled the song that they had learned before the meeting. After that, the students were asked questions by showing pictures according to the vocabulary in this song. All students remember the vocabulary in the lyrics of this song well. They remember all the English vocabularies related to sea animals in song lyrics.

From the meeting observation, it can be seen that Miko, Dastan, Abhi, Tama, Clairy, and Almirah are the most active students. It is because they like to know about animals and listen to stories about the sea with the song. The other students are Moniq, Karina, Ringgo, and Aftan do not stand out at every meeting. It is because they do not understand some words when learning activities. Generally, the students' performance in required the name of sea animals in English was almost perfect, although, there were some students could not do it.

Then on the last day of the second week, the simple pictures of post-test will be given by choosing multiple choices.

The fifth meeting was on March 19th, 2021. The students was given the post-test in the last meeting this week with the vocabulary contained in the song "A Sailor Went to Sea." The posttest is given in the form of a multiplechoice test and shows a picture containing seven questions based on the vocabulary in this song. The vocabulary taught in this meeting was described as follows:

Shark, octopus, jellyfish, turtle, dolphin, seahorse, swim, sea.

The result of post-test of the students is presented by using a table, vocabulary children songs entitled "A Sailor Went to Sea." as follows: 
KUMAROTTAMA: Jurnal Pendidikan Anak

Table 3.3 The result of the students post test from "A Sailor Went to Sea" song

\begin{tabular}{cccccccccc}
\hline No & $\begin{array}{c}\text { Student } \\
\text { names }\end{array}$ & \multicolumn{7}{c}{ Kinds of Vocabulary } \\
& Shark & Octopus & Jellyfish & Turtle & Dolphin & Seahorse & Swim & Sea \\
\hline 1. & Miko & $\sqrt{ }$ & $\sqrt{ }$ & $\sqrt{ }$ & $\sqrt{ }$ & $\sqrt{ }$ & $\sqrt{ }$ & $\sqrt{ }$ & $\sqrt{ }$ \\
2. & Moniq & $\sqrt{ }$ & X & $\sqrt{ }$ & $\sqrt{ }$ & $\sqrt{ }$ & $\sqrt{ }$ & $\sqrt{ }$ & $\sqrt{ }$ \\
3. & Dastan & $\sqrt{ }$ & $\sqrt{ }$ & $\sqrt{ }$ & $\sqrt{ }$ & $\sqrt{ }$ & $\sqrt{ }$ & $\sqrt{ }$ & $\sqrt{ }$ \\
4. & Abhi & $\sqrt{ }$ & $\sqrt{ }$ & $\sqrt{ }$ & $\sqrt{ }$ & $\sqrt{ }$ & $\sqrt{ }$ & $\sqrt{ }$ & $\sqrt{ }$ \\
5. & Karina & $\sqrt{ }$ & $\sqrt{ }$ & $\sqrt{ }$ & $\sqrt{ }$ & $\sqrt{ }$ & $\sqrt{ }$ & $\sqrt{ }$ & X \\
6. & Ringgo & $\sqrt{ }$ & X & X & $\sqrt{ }$ & $\sqrt{ }$ & $\sqrt{ }$ & $\sqrt{ }$ & X \\
7. & Tama & $\sqrt{ }$ & $\sqrt{ }$ & $\sqrt{ }$ & $\sqrt{ }$ & $\sqrt{ }$ & $\sqrt{ }$ & $\sqrt{ }$ & $\sqrt{ }$ \\
8. & Clairy & $\sqrt{ }$ & $\sqrt{ }$ & $\sqrt{ }$ & $\sqrt{ }$ & $\sqrt{ }$ & $\sqrt{ }$ & $\sqrt{ }$ & $\sqrt{ }$ \\
9. & Aftan & $\sqrt{ }$ & X & X & $\sqrt{ }$ & $\sqrt{ }$ & $\sqrt{ }$ & $\sqrt{ }$ & $\sqrt{ }$ \\
10. & Almirah & $\sqrt{ }$ & $\sqrt{ }$ & $\sqrt{ }$ & $\sqrt{ }$ & $\sqrt{ }$ & $\sqrt{ }$ & $\sqrt{ }$ & $\sqrt{ }$ \\
\hline
\end{tabular}

The symbol above $(\sqrt{ })$ indicates the students can acquire the vocabularies of body parts. Meanwhile $(X)$ indicates that the students cannot acquire the vocabulary. The following subsections are explanation about the result of the post-test, started from If you're happy songs.

The post-test results showed that the students had good vocabulary acquiring. This can be seen from the table above. there are six out of ten students who answered all questions correctly. They are Miko, Abhi, Dastan, Tama, Clairy, and Almirah. Four other students answered incorrectly on several questions related to the action song. Moniq made a mistake in

\section{CONCLUSION}

The English children songs are suitable media to be used in acquiring language for children. The songs contain fun rhyme, simple lyrics and octopus. Karina made a mistake in sea. Ringgo made a mistake. Aftan made mistakes in Octopus and jellyfish. In addition to knowing the vocabulary about sea animals, this song also plays pronunciation such as the words 'sea' and 'see' have the same pronunciation, the phonetic symbol can be read (sē).

In this song, eight vocabularies are related to sea animals obtained by the students found in the song entitled "A Sailor Went to Sea," such as shark, octopus, jellyfish, turtle, dolphin, seahorse, swim, sea. From the explanation above, this song can help the student to learn or acquired English vocabularies related to sea animals.

excited movements which make the students enthusiast in learning the song. The lyrics of those songs included easy words regarding to the title. As the result, the students can 
follow and remember the English vocabularies while singing the song. The English vocabularies acquired by the students are the lyrics of the songs entitled "If you're happy." and "A Sailor Went to Sea,". In the learning process, the students showed progress of acquiring language. For example, they start knowing the words, learning the words, and remembering the words. Most of the students are familiar and understand the vocabularies. However, there are some of them who still make mistake and harder to understand the vocabularies. Moreover, acquiring language with the help of song is very effective for the students.

\section{REFERENCES}

Aridna Suhcera. (2018). The Acquisition of Vocabulary by Using Children Song and Kinesthetic Learning Strategy in Bali Public School. Udayana University.

ASHA. (2020). American Speech Language Hearing Association. Speech-Language-Hearing Association (ASHA).

Brown, H. D. (2000). Principles of Language Learning and Teaching. Longman.

Chomsky Nuam. (1965). Aspects of the theory of Syntax. Cambridge. The MIT Press.

Connell, P. J. (1987). Teaching language rules as solutions tolanguage problems: A baseball analogy. Language, Speech, and Hearing Services in Schools.

Curtis, M. (2004). A sailor went to sea: Theme and variations. Folk Music Journal.

Fillmore, L. W., \& Snow, C. E. (2018).
What Teachers Need to Know About Language. Multilingual Matters.

Hasa. (2020). Difference Between First Language and Second Language Acquisition. PEDIAA. https://pediaa.com/differencebetween-first-language-andsecond-languageacquisition/\#: :text=sentences to communicate.-,First language acquisition is children's acquisition of their native language, an active and conscious process.

Kurniati, V. S. D., \& Widyastuti, I. (2019). Developing English Children Learning Media through Lyrics Visualization Developing English Children Learning Media through Lyrics Visualization. International Conference on Technology, Education and Sciences (InCoTES), 1(1), 122-129.

Noam Chomsky. (1972). Language and Mind. Harcourt Brace Jovanovich. Inc.

Sharon Novak. (2014). What Are the Characteristics of a Good Kids Song. Https://Www.Linkedin.Com/. https://www.linkedin.com/

Sugiyono. (2009). Metode Penelitian Pendidikan Pendekatan Kuantitatif, Kualitatif, dan RED. Bandung: Alfabeta.

Wiasti, N. K. (2021). Sekar Rare Sebagai Media Pembelajaran Nilai. Kumarottama: Jurnal Pendidikan Anak Usia Din, 1(1), 36-48. https://doi.org/https://doi.org /https://doi.org/10.53977/kum arottama.v1i1.267

Wiguna, Ida Bagus Alit \& Ekaningtyas, N. L. D. (2021). Strategi Orang Tua Dalam Mendampingi Anak Usia Dini Belajar Daring Di Rumah. PRATAMA WIDYA: JURNAL PENDIDIKAN ANAK USIA DINI, 
6(1),

86-95.

http://www.ejournal.ihdn.ac.id/ index.php/PW/article/view/214 1

Wiguna, I. B. A. A. (2020). Efektivitas Penerapan Metode Hypnoteaching Dalam Meningkatkan Aktivitas Belajar Siswa. PEMBELAJAR: Jurnal Ilmu Pendidikan, Keguruan, Dan Pembelajaran, 4(2). https://doi.org/10.26858/pembe

\section{lajar.v4i2.13006}

Wiguna, I. B. A. A. (2021). Pelatihan Dan Pengembangan Keterampilan Mengajar Guru Pendidikan Anak Usia Dini. SELAPARANG Jurnal Pengabdian Masyarakat Berkemajuan, 4(3), 533. https://doi.org/10.31764/jpmb. v4i3.4434 